\title{
Kuivalannan kaksivaiheinen jatkuvatoiminen mädätys maatilalla: Reakto- rin rakenne sekä aine-, ravinne- ja energiataseet
}

\author{
Winfried Schäfer ${ }^{1)}$, Lars Evers ${ }^{2)}$, Marja Lehto ${ }^{1)}$, Sanna Sorvala ${ }^{1)}$, Frederick Teye ${ }^{1)}$, Artur Granstedt ${ }^{2)}$ \\ ${ }^{1)}$ MTT Maatalousteknologian tutkimus, Vakolantie 55,03400 Vihti, winfried.schafer@mtt.fi \\ ${ }^{2)}$ Biodynamic Research Institute, Skilleby gård, S-15391 Järna, sbfi@jdb.se
}

\section{Tiivistelmä}

Viime vuosikymmeninä on maatiloille kehitetty muutamia kuivamädätyslaitosten prototyyppejä. Kuivamädätyslaitosten etuja, verrattuna lietteiden mädätyslaitoksiin, ovat pienempi reaktorin koko, prosessienergian kulutus ja kuljetustarve sekä pienemmät hajukaasupäästöt. Kuivamädätyslaitokset eivät kuitenkaan ole yleistyneet maatiloilla, koska reaktorin syöttö- ja tyhjennysvaiheet ovat olleet hankalia toteuttaa. Tässä esitetään uudenlainen kaksivaiheinen tilatason biokaasulaitos, joka on jatkuvatoiminen ja jolla mädätetään lypsykarjan kuivalantaa.

Lypsykarjatilalta tuleva kuivalanta siirretään hydraulisella raapalla hydrolyysireaktorin syöttökanavaan, josta se puristetaan hydrolyysireaktorin yläosaan. Reaktori on vinossa, $30^{\circ}$ kulmassa, ja sen tehollinen tilavuus on $53 \mathrm{~m}^{3}$. Tuore materiaali sekoittuu muuhun materiaaliin painovoiman avuilla. Viipymäaika on 22 - 25 päivää $38^{\circ} \mathrm{C}$ :ssa, minkä jälkeen materiaali poistetaan reaktorin alaosasta laatikon avulla. Osa materiaalista putoaa kuljetusruuvin alapuolella olevaan puristimeen, missä erotetaan toisistaan kiinteä ja nestemäinen jae. Toinen osa johdetaan takaisin syöttökanavaan ja syötetään tuoreen lannan sekaan. Kiinteä jae, joka saadaan puristimesta, kompostoidaan lantalassa. Nestemäinen jae kerätään ja pumpataan metaanireaktoriin, jonka tehollinen tilavuus on $17 \mathrm{~m}^{3}$. Nestemäinen jae, altaasta ja metaanireaktorista, palautetaan osittain syöttöputkeen, tukkeutumisen estämiseksi. Mädätetty neste pumpataan 15 - 16 päivän hydraulisen viipymäajan jälkeen varastosäiliöön. Vertailukokeessa kompostoitiin rinnakkain käsittelemätöntä lantaa sekä hydrolyysireaktorista tulevaa kiinteää jaetta.

Biokaasulaitos tuotti kaasua keskimäärin $52 \mathrm{~m}^{3}$ vuorokaudessa, suurin mitattu saanto vuorokaudessa oli $91 \mathrm{~m}^{3}$ biokaasua tai metaanin määränä ilmaistuna $0,17 \mathrm{~m}^{3} \mathrm{CH}_{4}$ orgaanista kuiva-ainekiloa kohti. Kiinteä jae sisälsi $73 \pm 2 \%$ syötetystä orgaanisesta kuiva-aineesta ja nestemäinen mädätysjäännös $10 \pm 2 \%$. Kompostoitu kiinteä jae ja nestemäinen mädätysjäännös sisälsivät yhteensä $70-81 \%$ kuivalannan kokonaistyppimäärästä ja 94 - $111 \%$ kuivalannan ammoniumista. Kokonaistyyppihäviö oli 19 - $29 \%$. Lannan kompostoinnissa ammoniumhäviö oli $96 \%$ ja kokonaistyyppihäviö $30-48 \%$. Tuotetusta metaanista kului keskimäärin $76,3 \%$ prosessin lämmittämiseen ja enimmillään $56 \%$ tuotetusta energiasta (305 $\left.\mathrm{kWh} \mathrm{d}^{-1}\right)$ oli käytettävissä maatilan lämmitykseen.

Kaksivaiheinen biokaasureaktorin prototyyppi on toimiva ratkaisu Ytterenebyn maatilan ja läheisen elintarvikeyrityksen orgaanisen jätteen käsittelyyn. Biokaasulaitoksen rakenteessa on otettu huomioon uusimmat tutkimustulokset. Prosessioptimoinnin jälkeen taloudellinen arviointi on tarpeellista arvioitaessa uuden tekniikan kilpailukykyä.

\section{Asiasanat}

Biokaasu, kuivalanta, mädätys, jatkuvatoiminen prosessi, maatilataso 


\section{Johdanto}

Nykyisin myynnissä olevat biokaasulaitokset on kehitetty pääasiassa lietteiden ja muiden orgaanisten aineiden mädätykseen. Kuivalantaketjua käyttävien nauta-, hevos- ja siipikarjatilojen kilpailukykyä rajoittaa se, että lietemenetelmään siirtyminen vaatii merkittäviä lisäinvestointeja. Kiinteiden yhdyskuntabiojätteiden käsittelemiseen kehitetty teknologia on edistänyt myös maataloudessa käytettävien ns. kuivamädätyslaitosten kehitystä. Näissä laitoksissa käytettävän raaka-aineen kuiva-ainepitoisuus on $15-50 \%$ (Hoffman 2001). Tällaisten laitosten etuja, verrattuna lietteen mädätyslaitoksiin, ovat reaktorin pienempi koko, prosessin pienempi energiakulutus, vähäisempi kuljetustarve sekä pienemmät hajukaasupäästöt.

Maatilatason tutkimuksissa, jotka käsittelevät kuivamädätystä panosreaktoreissa (Gronauer ja Aschman 2004, Kusch ja Oechsner 2004) sekä prototyyppitutkimuksessa (Linke 2004), on todettu, että täyttö- ja poistovaiheet ovat panosreaktorissa hankalia ja/tai vievät paljon aikaa verrattuna lietereaktoreihin. Tasainen kaasuntuotanto edellyttää useaa peräkkäistä panosreaktoria, joita täytetään tietyin aikavälein. Baserga ym. 1994 kehittivät tilatasolle $9,6 \mathrm{~m}^{3}: \mathrm{n}$ pilottilaitteiston, joka mädättää jatkuvatoimisesti kiinteää lihakarjan lantaa. Kuivamädätyslaitokset eivät kuitenkaan ole yleistyneet ja niitä on vähän kaupallisesti saatavilla. Testattujen teknisten ratkaisujen puute ja vähäiset tilatason tutkimustulokset ovat pääasiassa syynä kuivamädätysteknologian vähäisyyteen maatiloilla.

Tässä tutkimuksessa saatiin tietoa uudenlaisesta, kaksivaiheisesta tilatason biokaasulaitoksesta. Laitos käsittelee lypsykarjan lantaa ja tilan sekä läheisen elintarvikeyrityksen orgaanista jätettä. Kaksivaiheista reaktoritekniikkaa on käytetty siksi, että tällä saadaan erotettua nestemäinen ja kiinteä jae toisistaan. Kiinteä jae kompostoidaan hydrolyysivaiheen jälkeen. Nestemäisen jakeen anaerobisessa mädätyksessä voidaan käyttää biofilmiteknologiaa, jonka etuja ovat lyhyt hydraulinen viipymä, pienempi reaktoritilavuus ja biokaasun suurempi metaanipitoisuus, verrattuna ilman suodatinmateriaalia toimiviin reaktoreihin, (Lo ym. 1984).

\section{Aineisto ja menetelmät}

Biokaasulaitos sijaitsee Ytterenebyn tilalla Järnassa, Ruotsissa, noin $50 \mathrm{~km}$ Tukholmasta etelään. Laitos on suunniteltu käsittelemään kuivalantaa, jota saadaan 65 eläinpaikkaisesta lypsykarjanavetasta, sekä läheisen elintarvikeyrityksen orgaanista jätettä, kuva 1 .

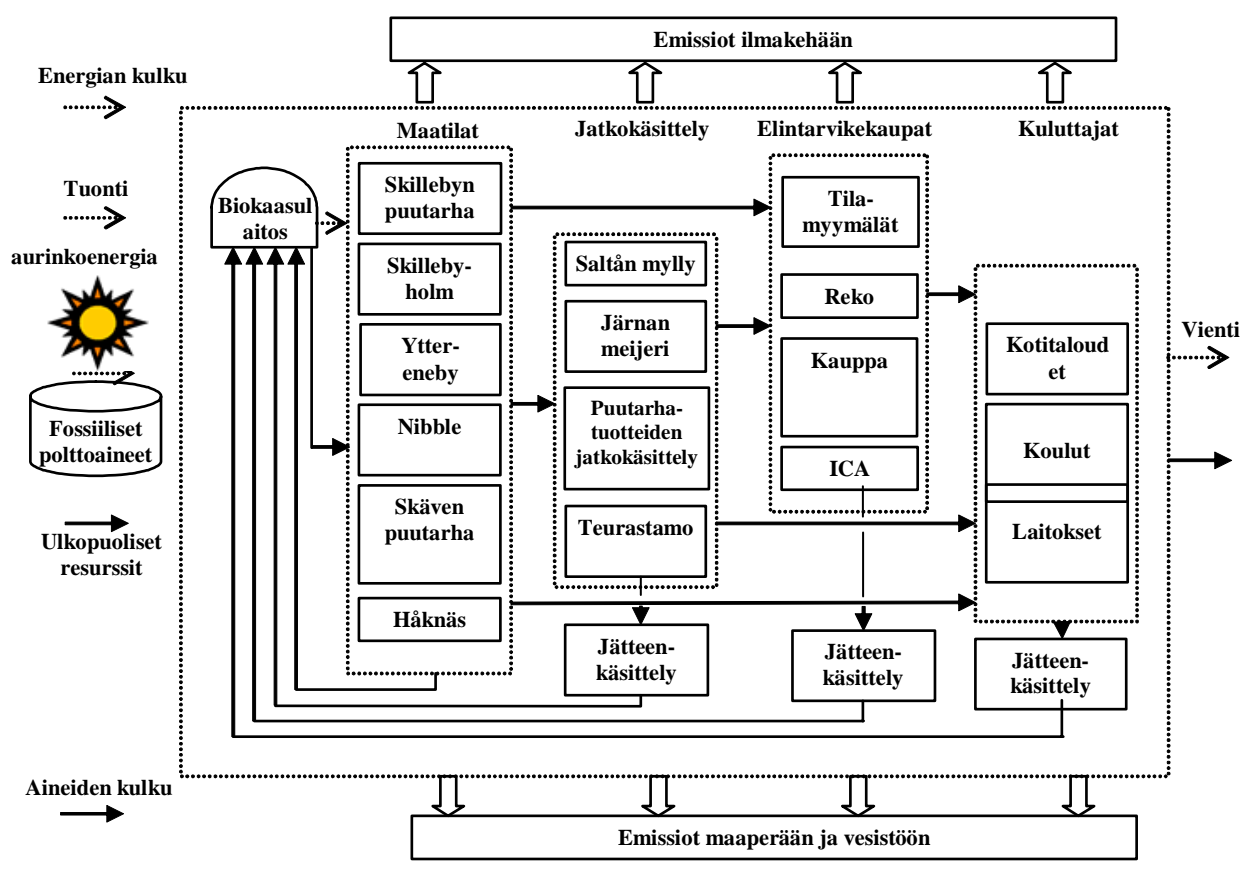

Kuva 1: Pääperiaate kokonaisuudesta, johon Järnan biokaasulaitos sijoittuu. Tavoitteena on korkea kierrätysaste, uusiutumattoman energian käytön vähentäminen sekä parhaan tunnetun ekologisen teknologian käyttö järjestelmän jokaisessa vaiheessa. Tavoitteena on vähentää uusiutumattomien luonnonvarojen käyttöä ja vähentää haitallisia päästöjä ilmakehään, maaperään ja vesistöihin (Granstedt ym. 2005). 


\section{Laitoksen rakenne}

Biokaasulaitoksen molemmat reaktorit on valmistettu COR-TEN-terässylinteristä, jota on aikaisemmin käytetty savupiippuna. Sylinterin seinämän paksuus on $10 \mathrm{~mm}$ ja sisähalkaisija 2,85 m. Sylinteri on päällystetty $20 \mathrm{~cm}$ paksulla selluvillaeristeellä sekä poimulevyllä. Kuvassa 2 on esitetty biokaasulaitoksen prosessivirtauskaavio.

Lypsykarjatilan parsinavetassa on 65 eläinpaikkaa. Kuivalanta on sekoitus sonnasta, oljesta ja kaura-akanoista. Lanta siirretään hydraulisella raapalla hydrolyysireaktorin syöttökanavaan. Syöttökanavasta lanta puristetaan toisella hydraulisella raapalla (180 bar, $2700 \mathrm{~mm}$ isku) $400 \mathrm{~mm}$ leveän PVC-putken läpi hydrolyysireaktorin yläosaan. Reaktori on vinossa, $30^{\circ}$ kulmassa, ja sen tehollinen tilavuus on $53 \mathrm{~m}^{3}$. Tuore materiaali sekoittuu muuhun materiaaliin painovoiman avuilla. Hydrolyysireaktorin pohjalla, syöttöputken molemmilla puolilla, ovat kuumavesikanavat. Hydraulisen viipymän, 22 - 25 päivää $38{ }^{\circ} \mathrm{C}$ :ssa, jälkeen materiaali poistetaan reaktorin alaosasta pohjatonta laatikkoa käyttäen. Laatikko kulkee suorakulmaisessa kanavassa hydraulisen sylinterin avulla (180 bar, $1000 \mathrm{~mm}$ is$\mathrm{ku})$. Jokainen työntö poistaa reaktorista noin $0,1 \mathrm{~m}^{3}$ materiaalia alapuolella olevaan kuljetusruuviin (Spirac, Ø $260 \mathrm{~mm}$ ). Osa materiaalista putoaa kuljetusruuvin alapuolella poikittain olevaan puristimeen (Spirac, Ø $200 \mathrm{~mm}$ ), missä erotetaan toisistaan kiinteä ja nestemäinen jae. Toinen osa johdetaan takaisin syöttökanavaan ja syötetään tuoreen lannan sekaan. Kuivajae, joka saadaan puristimesta, kompostoidaan lantalassa.

Nestemäinen jae kerätään $2 \mathrm{~m}^{3}: \mathrm{n}$ välivarastoon, josta se pumpataan metaanireaktoriin. Nestemäinen jae, välivarastosta ja metaanireaktorista, palautetaan osittain syöttöputkeen tukkeutumisen estämiseksi. Metaanireaktori on $4 \mathrm{~m}$ korkea ja sisältää 10.000 muovista suodatinkappaletta. Reaktorin tehollinen tilavuus on $17,6 \mathrm{~m}^{3}$. Hydraulisen viipymän, $15-16 \mathrm{~d} 38^{\circ} \mathrm{C}$ :ssa, jälkeen neste pumpataan ruuvipumpulla (Pumpenfabrik, Wangen, Typ KL 30S-500) neljän paineilmalla ohjatun venttiilin kautta varastosäiliöön, jota peittää kelluva kangas. Molemmissa reaktoreissa muodostunut kaasu kuivataan ja varastoidaan säkissä. Kompressori, joka tuottaa 170 mbar paineen, syöttää kaasua laitoksen prosessipolttimeen sekä kartanon lämmityskattilan polttimeen. Biokaasulaitosta ohjataan Mitsubishi FX 2N 48 MR ohjelmoitavan logiikan ohjauslaitteella.

\section{Näytteenotto}

Molemmista reaktoreista saatavaa kaasumäärää mitattiin kaasumittareilla (Actaris G6 RF1) ja lukemat luettiin päivittäin. Biokaasun $\mathrm{CO}_{2}$-pitoisuus määritettiin natriumhydroksidiliuoksen avulla. Biokaasun höyrypitoisuuden arvioitiin olevan $3 \%$ (Weiland 2004). Keväällä 2004 asennettiin kolmas kaasumittari (Krom-Schröder BK-G4T) rekisteröimään prosessilämmittimen kaasunkulutusta, lisäksi mitattiin koko laitoksen sähkönkulutusta.

Näytteenotto suoritettiin tilalla kolmena ajankohtana: 3.3., 6.5. ja 26.10.2004. Syöttökanavasta otettiin lantanäytteet, samoin kiinteästä jakeesta, laitoksesta poistuvasta nesteestä, oljesta ja akanoista. Kompostointikokeet tehtiin ajanjaksoina 10.5.-13.8.2004 ja 27.10.2004-16.3.2005. Rinnakkain kompostoitiin käsittelemätöntä lantaa sekä hydrolyysireaktorista poistuvaa kuivajaetta. Näytteiden tilavuus oli 501 ja ne kompostoitiin $15{ }^{\circ} \mathrm{C}$ ja $20^{\circ} \mathrm{C}$ lämpötiloissa MTT/Vakolan säähuoneessa. Kuivaaine ja ravinnepitoisuudet määritettiin HS miljölab Ab:ssä Ruotsissa ja Novalab Oy:ssä Suomessa. Orgaaninen kiintoaine analysoitiin MTT/Vakolan laboratoriossa $\left(3 \mathrm{~h} 550{ }^{\circ} \mathrm{C}: \mathrm{ssa}\right)$.

\section{Tulokset ja tulosten tarkastelu}

Kevään tulokset ovat keskiarvoja näytteistä, jotka otettiin 3.3.2004 ja 6.5.2004. Syksyn tulokset ovat näytteistä, jotka otettiin 26.10.2004.

\footnotetext{
Ainetase

Taulukossa 1 on esitetty biokaasulaitoksen ainetase. Biokaasulaitokseen syötetystä orgaanisesta materiaalista $53-70 \%$ oli peräisin kaura-akanoista ja oljesta. Kiinteässä jakeessa oli jäljellä $70-75 \%$, nestejakeessa $10-15 \%$ ja biokaasussa 14,5 - $15 \%$ kokonaiskuiva-aineesta. Kompostoitu kiinteä jae ja nestejae sisälsivät yhteensä n. 48 \% laitokseen syötetyn materiaalin kuiva-aineesta. Käsittelemättömän lannan kompostoinnissa kuiva-ainehäviö oli n. 47 - $49 \%$.
} 


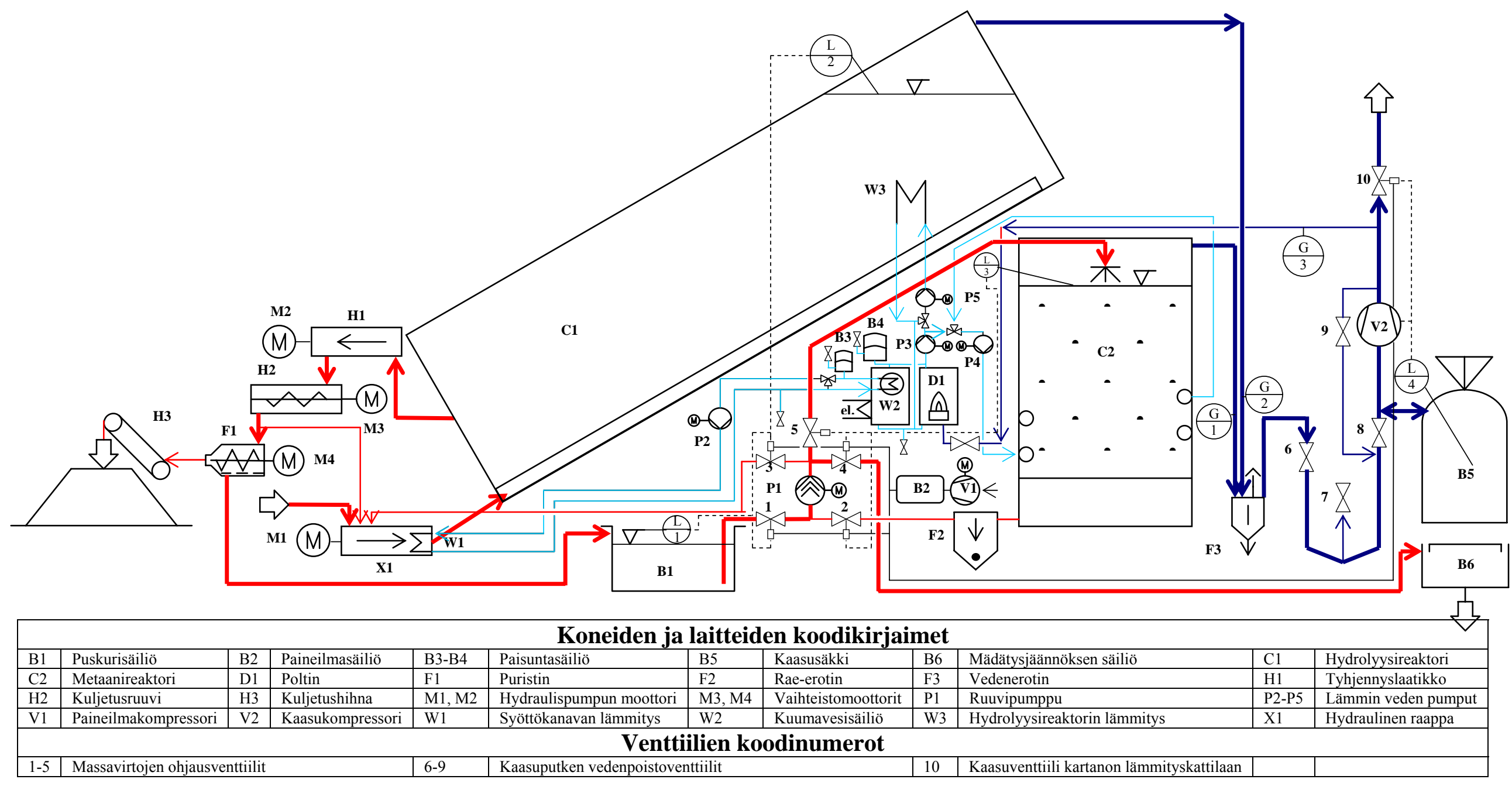

\begin{tabular}{|c|c|c|c|c|c|c|c|c|c|c|c|c|c|}
\hline \multicolumn{14}{|c|}{ Mittaus- ja ohjaustoiminnan koodikirjaimet } \\
\hline$\frac{1}{1}$ & $\begin{array}{l}\text { Puskurisäiliön pinta- } \\
\text { korkeusanturi }\end{array}$ & $\frac{1}{2}$ & $\begin{array}{l}\text { Hydrolyysireaktorin } \\
\text { pintakorkeusanturi }\end{array}$ & $\frac{1}{3}$ & $\begin{array}{l}\text { Metaanireaktorin } \\
\text { pintakorkeusanturi }\end{array}$ & $\frac{1}{4}$ & $\begin{array}{l}\text { Kaasusäkin täyt- } \\
\text { töasteen anturi }\end{array}$ & $\frac{G}{1}$ & $\begin{array}{l}\text { Metaanireaktorin } \\
\text { kaasumittari }\end{array}$ & $\frac{G}{2}$ & $\begin{array}{l}\text { Hydrolyysireakto- } \\
\text { rin kaasumittari }\end{array}$ & $\frac{G}{3}$ & $\begin{array}{l}\text { Polttimen } \\
\text { kaasumittari }\end{array}$ \\
\hline
\end{tabular}

Kuva 2: Biokaasulaitoksen prosessivirtauskaavio, Yttereneby, Järna 
Biokaasulaitos tuotti kaasua keskimäärin $52 \mathrm{~m}^{3} \mathrm{~d}^{-1}$, suurin mitattu saanto vuorokaudessa oli $91 \mathrm{~m}^{3}$ biokaasua tai metaanin määränä ilmaistuna $0,17 \mathrm{~m}^{3} \mathrm{CH}_{4} \mathrm{~kg}^{-1} \mathrm{VS}$. Basergan ym. (1994) tutkimuksen mukaan lihakarjan lannan biokaasutuksesta saatiin metaania $0,186 \mathrm{~m}^{3} \mathrm{CH}_{4} \mathrm{~kg}^{-1} \mathrm{VS}$. Møller ym. (2004) saivat lypsykarjan lannan mädätyksen metaanisaannoksi $0,1-0,16 \mathrm{~m}^{3} \mathrm{CH}_{4} \mathrm{~kg}^{-1} \mathrm{VS}$.

Taulukko 1: Keväällä ja syksyllä 2004 mitattujen näytteiden ainetase: Tuoremassa FM, kuiva-aine TS ja orgaaninen kuiva-aine VS.

\begin{tabular}{|l|r|r|r|r|r|r|}
\hline Massa & \multicolumn{2}{|c|}{ FM kg d $^{-\mathbf{1}}$} & \multicolumn{2}{|c|}{ TS kg d $^{-\mathbf{1}}$} & \multicolumn{2}{c|}{ VS kg d $^{-\mathbf{1}}$} \\
\hline \multicolumn{1}{|c|}{2004} & Kevät & Syksy & Kevät & Syksy & Kevät & Syksy \\
\hline Syötetty sonta & 1717 & 2175 & 123 & 199 & 99 & 176 \\
\hline Syötetty olki & 27 & 58 & 24 & 44 & 23 & 37 \\
\hline Syötetty kaura-akana & 256 & 198 & 238 & 181 & 218 & 162 \\
\hline Syötetty yhteensä & $\mathbf{2 0 0 0}$ & $\mathbf{2 4 3 0}$ & $\mathbf{3 8 5}$ & $\mathbf{4 2 4}$ & $\mathbf{3 4 0}$ & $\mathbf{3 7 6}$ \\
\hline Poistuva kiinteä jae & 919 & 1188 & 271 & 317 & 243 & 282 \\
\hline Poistuva neste & 1025 & 1176 & 58 & 45 & 41 & 32 \\
\hline Poistuva $\mathrm{CO}_{2}$ & 34 & 40 & 34 & 40 & 34 & 40 \\
\hline Poistuva CH $\mathrm{CH}_{4}$ & 21 & 22 & 21 & 22 & 21 & 22 \\
\hline Poistuva vesihöyry & 1 & 2 & & & & \\
\hline Poistuva yhteensä & $\mathbf{2 0 0 0}$ & $\mathbf{2 4 2 8}$ & $\mathbf{3 8 4}$ & $\mathbf{4 2 3}$ & $\mathbf{3 3 9}$ & $\mathbf{3 7 5}$ \\
\hline
\end{tabular}

\section{Ravinnetase}

Taulukkoon 2 on koottu eri jakeista määritetyt ravinnepitoisuudet ja kuvassa 3 on esitetty typen esiintyminen erilaisina typen yhdisteinä. Kokonaistypen häviöt vaihtelivat mädätyksessä $19-29 \%$ ja käsittelemättömän lannan kompostoinnissa välillä 30 - $48 \%$. Samansuuntaisia arvoja mitattiin myös ammoniumille, häviö lannan anaerobisessa mädätyksessä oli vain $6 \%$, mutta lannan aerobisessa kompostoinnissa se oli $96 \%$. Kaliumin ja fosforin häviöt olivat suuremmat anaerobisessa kuin aerobisessa hajotuksessa. Kompostoitu kiinteä jae ja nestejae sisälsivät yhteensä laitokseen syötetystä kokonaistypestä $70-81 \%$ ja ammoniumtypestä $94-111 \%$. Tulokset vahvistavat Möllerin (2002) laskelmia, joiden mukaan biokaasutuotanto lisää ammoniakin kiertoa ja vähentää typen häviötä verrattuna pelkkään aerobiseen kompostointiin.

Taulukko 2: Biokaasulaitokseen syötetyn ja sieltä poistuvan materiaalin ravinnepitoisuudet. $\mathrm{N}_{\text {tot }}$ on kokonais-N.

\begin{tabular}{|c|c|c|c|c|c|c|}
\hline Ravinne & \multicolumn{2}{|c|}{$\mathrm{N}_{\text {tot }} \mathrm{kg} \mathrm{d}^{-1}$} & \multicolumn{2}{|c|}{$\mathrm{K} \mathrm{kg} \mathrm{d}^{-1}$} & \multicolumn{2}{|c|}{$P$ kg d $^{-1}$} \\
\hline 2004 & Kevät & Syksy & Kevät & Syksy & Kevät & Syksy \\
\hline Syötetty sonta & 8,29 & 7,68 & 6,06 & 10,02 & 2,01 & 1,40 \\
\hline Syötetty olki & 0,14 & 0,24 & 0,61 & 0,31 & 0,04 & 0,05 \\
\hline Syötetty kaura-akana & 0,56 & 0,59 & 1,13 & 1,09 & 0,20 & 0,20 \\
\hline Syötetty lanta & 9,00 & 8,50 & 7,80 & 11,42 & 2,25 & 1,65 \\
\hline Poistettu kiinteä jae & 3,95 & 4,40 & 2,85 & 4,63 & 0,76 & 0,84 \\
\hline Poistettu neste & 3,79 & 2,94 & 3,49 & 3,76 & 0,81 & 0,60 \\
\hline Poistettu yhteensä & 7,74 & 7,34 & 6,33 & 8,40 & 1,57 & $\overline{1,44}$ \\
\hline Häviö & 1,26 & 1,17 & 1,47 & 3,02 & 0,68 & 0,21 \\
\hline
\end{tabular}

\section{Energiatase}

Kuvassa 4 on esitetty biokaasulaitoksen tuottama ja kuluttama energiamäärä ajalta 23.11.2003 7.5.2004. Päivän keskilämpötila oli tuona ajanjaksona $0,4{ }^{\circ} \mathrm{C}$. Tuotetusta metaanista kului keskimäärin $76,3 \%$ prosessin lämmittämiseen. Enintään $56 \%$ tuotetusta energiasta jäi kartanon lämmitykseen. Laskennallisesti lämpöenergiaa kului lannan ja nestemäisen jakeen lämmitykseen 53,3 \% ja lämpöhäviöihin vain 9,5\% tuotetusta energiasta. Koko biokaasulaitoksen suurin saavutettu hyötysuhde oli n. 
49 \% ja keskimääräinen hyötysuhde $24 \%$ tuotetusta energiasta. Biokaasureaktorin kokonaislämmönkulutus oli $206 \mathrm{kWh} / \mathrm{d}$ ja sähköenergian kulutus $32 \mathrm{kWh} / \mathrm{d}$.

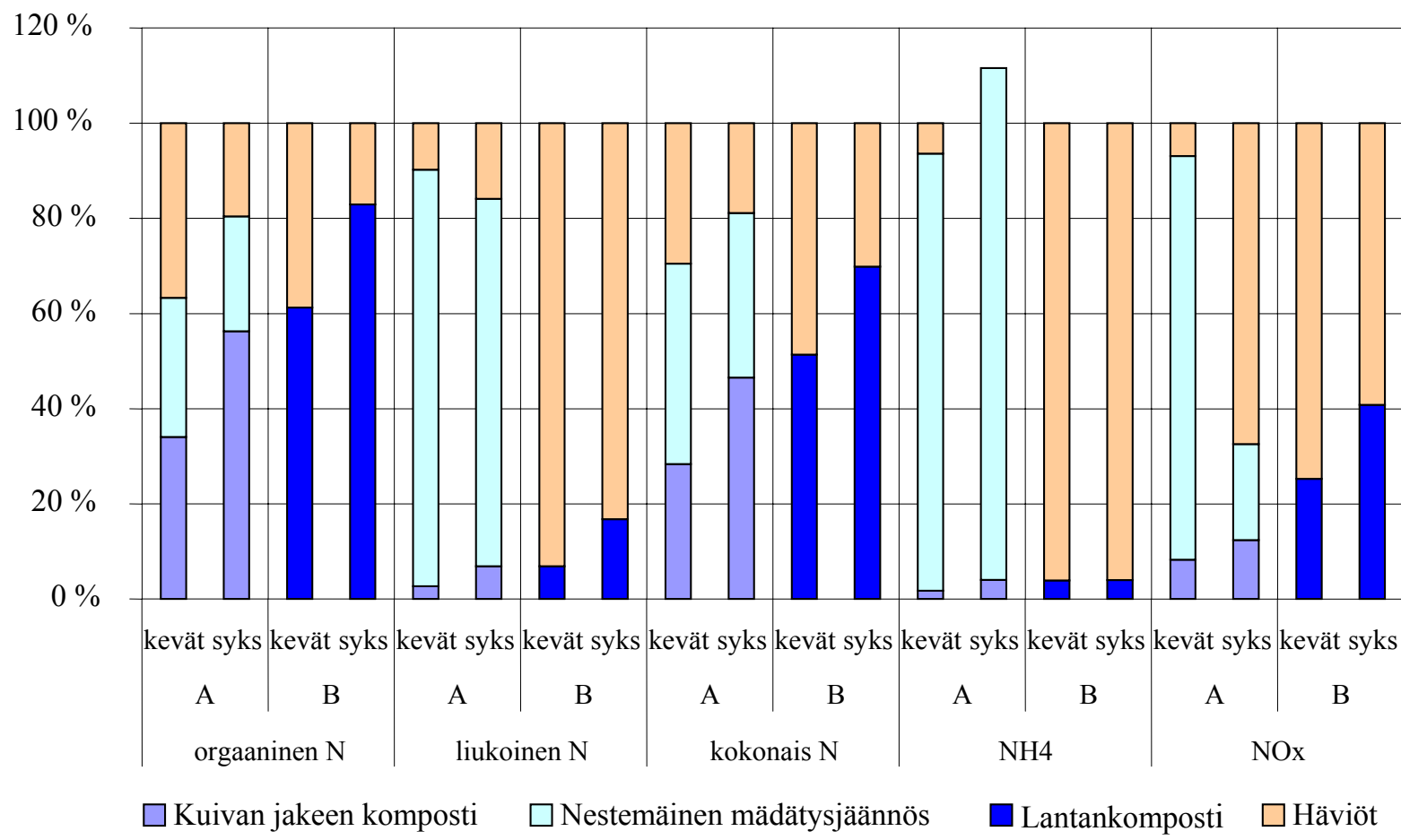

Kuva 3: Biokaasulaitoksen (A) ja aerobisen kompostin (B) typpitase keväällä ja syksyllä 2004. $100 \%=$ syötetyn lannan typpimäärä.

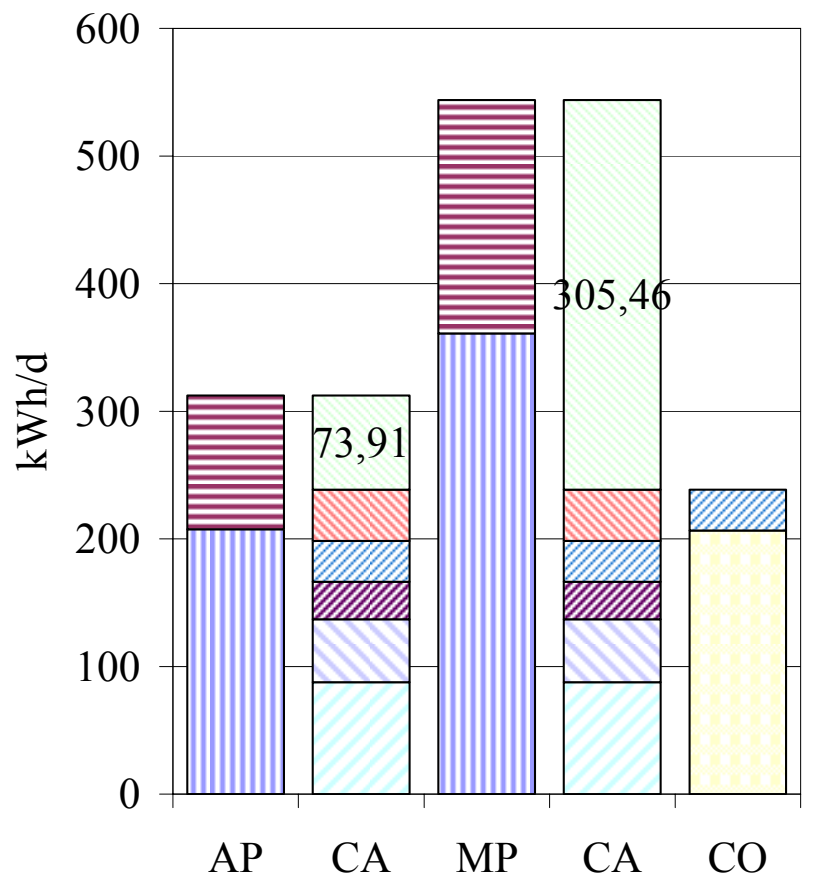

$\square$ Energian ylijäämä

$\mathbb{Q}$ Muut energiahäviöt

Ø Sähkön kulutus

$\square$ Mitattu prosessilämmön tarve

叉Reaktoreiden lämpöhäviöt

$\square$ Nestemäisen jakeen lämmitystarve

$\square$ Lannan lämmitystarve

目 Metaanireaktorin tuotto

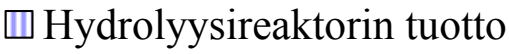

Kuva 4: Biokaasulaitoksen tuottama ja kuluttama energia. AP: keskimääräinen metaanintuotto. CA: laskettu energian kulutus. MP: maksimi metaanin tuotto. CO: mitattu energian kulutus. 


\section{Johtopäätökset}

Järnassa sijaitseva kaksivaiheinen biokaasulaitos on toimiva ratkaisu maatilan ja läheisen elintarvikeyrityksen orgaanisen jätteen käsittelyyn. Prototyyppireaktorin rakenteessa on otettu huomioon uusimmat tutkimustulokset. Lisää teknisiä ratkaisuja kuitenkin tarvitaan korkean kuiva-ainepitoisuuden omaavan orgaanisen materiaalin käsittelyyn ja prosessien optimointiin.

Edellä esitetty jatkuvatoiminen lannan syöttö- ja poistotekniikka soveltuu maatilan orgaanisen materiaalin koostumukselle ja kuiva-ainepitoisuudelle. Se ei välttämättä kuitenkaan sovi suurille olkimäärille tai viherjätteelle. Verrattuna pelkkään kompostointiin, orgaanisen materiaalin mädätys ja sen jälkeen kiinteän jakeen kompostointi, parantavat maatilan energia- ja ravinnetasetta. Avaintekijä on kuitenkin tarkoituksenmukainen, uusi tekniikka. Jotta Järnan biokaasulaitoksen tulokset voidaan varmistaa tilastollisesti, tarvitaan kuitenkin lisää mittauksia. Hydraulisen viipymäajan ja kuormituksen optimoinnilla voidaan päästä suurempaan kaasuntuotantoon, mutta tähän tarvitaan parempaa mittaustekniikkaa.

Taloudellinen arviointi on tarpeellista arvioitaessa uuden tekniikan kilpailukykyä. Biokaasulaitoksesta saatavaa hyötyä voidaan parantaa, jos otetaan huomioon paitsi reaktorin ravinnetase myös koko tilan ravinnetase viljelykiertokauden aikana. Ravinteiden laatu vaikuttaa maaperän viljavuuteen, sen kautta rehun laatuun ja lopulta eläinten terveyteen.

\section{Kirjallisuus}

Baserga, U., Egger, K., Wellinger, A. 1994. Biogas aus Festmist. Entwicklung einer kontinuierlich betriebenen Biogasanlage zur Vergärung von strohreichem Mist. Eidgenössische Forschungsanstalt für Agrarwirtschaft und Landtechnik (FAT) Tänikon. FAT-Berichte Nr. 451, 12p.

Granstedt, A., Thomsson, O. and Schneider, T. 2005. BERAS WP2 draft report August 2005. http://www.jdb.se/beras/

Gronauer, A. \& Aschmann, V. 2004. Wissenschaftliche Begleitung einer Pilotanlage zur Feststoffvergärung von landwirtschaftlichen Gütern. Gelbes Heft Nr. 77 des Bayerischen Staatsministeriums für Landwirtschaft und Forsten in München. 140p.

Hoffmann, M. 2001. Trockenfermentation. Entwicklungsstand und Perspektiven. Landtechnik 56, 410-411.

Kusch, S., Oechsner, H. 2004. Feststoffvergärung in Batchreaktoren - erste Veruchsergebnisse. In Tagungsband zur 13. Jahrestagung, Biogas und Bioenergie in der Landwirtschaft. 2.-4. Dezember 2004 in Wolpertshausen. (Ed. Internationales Biogas und Bioenergie Kompetenzzentrum, Fachgruppe Biogas), 115-124.

Linke, B. 2004. Substrateinsatz bei der Trockenfermentation - Einschätzung des F+E-Bedarfs. In Gülzower Fachgespräche 23, Fachagentur Nachwachsende Rohstoffe, 35-48.

Lo, K. V., Liao, P. H., Bulley, N. R., Chieng, S. T. 1984. A comparison of biogas production from dairy manure filtrate using conventional and fixed-film reactors. Canadian Agricultural Engineering 26, 73-78.

Möller, K. 2003. Systemwirkungen einer "Biogaswirtschaft" im ökologischen Landbau: Pflanzenbauliche Aspekte, Auswirkungen auf den N-Haushalt und auf die Spurengasemissionen. Biogas Journal 1, 20-29.

Møller, H., Sommer, S., Ahring, B. 2004. Methane productivity of manure, straw and solid fractions of manure. Biomass \& Bioenergy 26, 485-495.

Weiland, P. 2004. Notwendigkeit der Biogasaufbereitung und Stand der Technik. Ed. Fachagentur für Nachwachsende Rohstoffe e.V. In: Workshop Aufbereitung von Biogas. Gülzower Fachgespräche Bd. 21, Gülzow, 23-35. 